\title{
NON SURGICAL LATROGENIC PERFORATION REPAIR USING MINERAL TRIOXIDE AGGREGATE AND DIRECT RESTORATION WITH FIBER POST ON CENTRAL MAXILLARY INCISOR
}

\author{
Hendargo Agung Pribadi dan Yulita Kristanti \\ Department of Conservative Denstistry \\ Faculty of Dentistry- Universitas Gadjah Mada \\ Email: jodarjo@gmail.com
}

\begin{abstract}
ABSTRAK
Perforasi dapat menjadi masalah penyebab kegagalan perawatan saluran akar dalam jangka panjang. Perforasi dapat disebabkan oleh faktor iatrogenik. Perforasi iatrogenik yang paling umum ditemukan pada anterior rahang atas. Perbaikan perforasi iatrogenik non operasi dapat dilakukan dengan menggunakan agregat trioksida mineral dan restorasi langsung. Tujuan laporan kasus ini adalah untuk mendeskripsikan perbaikan perforasi iatrogenik nonbedah dengan menggunakan agregat trioksida mineral dan restorasi langsung dengan pos serat. Seorang pasien laki-laki berusia 27 tahun yang didiagnosis menderita pulpitis datang ke RSGM Prof. Soedomo. Perawatan saluran akar (pemadatan limbah) telah dilakukan sebelum dia dirujuk untuk perawatan lebih lanjut. Uji obyektif menunjukkan perkusi dan palpasi negatif. Dari radiograf periapikal dapat diketahui bahwa tidak ada berkas yang tertinggal di saluran akar. Perawatan saluran akar dilakukan dengan teknik step back dan kondensasi lateral. Perforasi disegel dengan agregat trioksida mineral. Gigi dipulihkan dengan restorasi langsung dengan fiber post. Perforasi latrogenik dapat diobati tanpa pembedahan menggunakan agregat trioksida mineral dan dipulihkan secara langsung menggunakan resin komposit dengan pos serat.
\end{abstract}

Kata Kunci: Agregat trioksida mineral; Perbaikan perforasi iatrogenik non-operasi; Perforasi latrogenik; Restorasi langsung.

\begin{abstract}
Perforation can be a problem that leading to root canal treatment failure in the long run. Perforation can be caused by iatrogenic factor. The most common iatrogenic perforation was found at maxillary anterior. Non surgery iatrogenic perforation repair can be done using mineral trioxide aggregate and direct restoration. The purpose of this case report was to describe non surgical iatrogenic perforation repair using mineral trioxide aggregate and direct restoration with fiber post. A 27 years old male patient diagnosed for pulpitis came to RSGM Prof. Soedomo. Root canal treatment (pulp extirpation) had performed before he was referred for further treatment. Objective test showed both percussion and palpation were negative. From periapical radiograph could be noticed that there was no file left in the root canal. Root canal treatment was performed using step back technique and lateral condensation. Perforation was sealed by mineral trioxide aggregate. The tooth was restored using direct restoration with fiber post. Latrogenic perforation can be treated non surgically using mineral trioxide aggregate and directly restored using composite resin with fiber post.
\end{abstract}

Keywords: Direct restoration; Latrogenic perforation; Mineral trioxide aggregate; Non-surgery iatrogenic perforation repair. 


\section{INTRODUCTION}

Nowadays, patients desire to get root canal treatment. Root canal treatment is one of treatment for either vital or non vital tooth with aiming preserve the tooth. The goal of endodontic is to eliminate microorganisms and necrotic pulp tissue debris, and to shape the root canal system to facilitate irrigation and placement of medicaments and obturation materials.

Reaching the outcome of endodontic treatment requiring good skills of taking diagnosis, radiograph interpretation, and performing treatment from open access phase until restoration the tooth. Perforation can be occurred during open access phase caused by misaligned use of rotary burs and searching for root canal orifices. Iatrogenic perforation can be a problem leading to root canal treatment caused by reinfection either from root canal or the periodontal tissue, or both.

The repair of iatrogenic perforations can be done with many different materials and techniques, one of them is mineral trioxide aggregate (MTA) use non surgically. Prognosis was poor when other materials were used before the introduction of MTA. This was probably often due to poor biocompatibility or the inadequate sealing ability of these materials. Since MTA was introducted in 1990s, MTA has demonstrated biocompatibility and bioactive.

Some studies showed endodontically treated teeth are more brittle than vital tooth, the other hand, the difference is not significant in other studies. Several cases about restoration post endodontic treatement with or without post placement have been evaluated. Post preparation procedure could lead the tooth more susceptible fracture. To prevent the fracture incident, some studies refers evaluation the rest of the tooth, selection of post material, type of post, length and width of the post. This paper will present a case about iatrogenic perforation which has been done with perforation repair with MTA, root canal treatment, and direct restoration with fiber post.

\section{Case}

A 27 yeas old male patient diagnosed for pulpitis came to RSGM Prof. Soedomo. From anamnesis, patient felt continuous pain at upper tooth. The tooth has been restored 3 years ago. Patient went to RSGM Prof. Soedomo and getting treatment with undergraduate student. The previous operator said that the tooth was irreversible pulpitis then endodontic treatment was done under anaesthesia. From working length confirmation radiograph interpretation, the operator confirmed the marker (K-file) go through out from the root canal system. The objective test showed there was a cavity inside the anatomical crown, both percussion and palpation were negative, and root canal system has not found yet. The marker (K-File \#8) was used for negotiating the connection of perforation through mucosa gingival.

Before undergoing treatment, the informed consent was taking by patient and the operator. Local anesthesia was done to block n. alveolar superior rami anterior using Pehacaine $2 \%$. Working area was isolated using dental rubber dam after detecting the perforation site using K-file. Exploring orifice was done carefully using rotary small diamond bur (Heico, Swiss). After locating the orifice, access straightening was done using non cutting tip tapered diamond bur (Diamendo, Heico, Swiss). K-File \#8 (Mailefer, Dentsply, Germany) was used to negotiate root canal system along two thirds root canal compared to diagnosis radiograph following smooth broach used for pushing aside dental pulp from root canal wall. Before performing root canal treatment, iatrogenic perforation was sealed by MTA with ratio $p: 1=3: 1$. MTA was condensed using small head hand plugger until fulfil the tunnel. A wet cotton pellet was placed to improve MTA setting, then temporary material placed on the cavity.

After one weak, root canal treatment would be done at this appointment. Isolation and anesthesia were done before the treatment. Dental pulp was extirpated using barbed broach (Colorinox, Dentsply, Germany) then irrigating $\mathrm{NaOCl}$ 2,5\% to dissolve remaining dental pulp and ethylenediaminetetraacetic acid (EDTA) 15\% to remove smear layer which produced during instrumentation. Working length confirmed by radiograph and electric 
apex locater (Raypex 5, VDW, Germany). Root canal treatment was done using step back technique and lateral condensation. Resin based sealer (Top seal, Dentsply, Germany) and gutta percha were selected for obturation material to establish resin monoblock system.

Two weeks later, patient was recalled for restoration step while taking evaluation last treatment. Due to economical reason, the restoration could not be an ideal such as crown (all porcelain, porcelain fused to metal, or composite resin). Direct restoration was offered as an alternative treatment for patient. The old restoration was preserved in order as frame for root canal treatment and as palatal index for direct restoration with mock up technique. Before removing the old restoration, maxillary anterior was impressed using putty type silicone based impression material (Aquasil Putty Type, Dentsply, Germany). The old restoration was removed while preparing tooth, removing enamel unsupported dentin, and creating short bevel. The restoration using total etch technique bonding system (Primenbond One, Dentsply, Germany).

Fiber post (Radix Fiber Post, Dentsply, Germany) was used to reinforce crown and root while producing intra canal retention for restoration material. Retention and resistance factors were obtained using silanized fiber post and resin based self adhesive resin cement (SmartCem2, Dentsply, Germany). After fiber post placement, bulkfill composite resin flowable type (SDR, Dentsply, Germany) was used to fulfil the gap between fiber post and dentin. Nanohybrid type with spherical filler composite resin (SphereTec, Dentsply, Germany) was chosen to achieve the restoration's look closer to adjacent tooth. Based on button technique shading match, A3 was selected for based on cervical, A2 for cervical to half, while A1 for the rest. All resin based materials were activated using LED light cure. The restoration was finished by abrasive rubber silicone rotary (Enhance Finishing System, Dentsply, Germany). Polishing step was done using aluminium oxide based materials such pasta (Prisma Gloss, Dentsply, Germany) and rotary (EVE Diapol, EVE, Germany).

\section{RESULT AND DISCUSSION}

In this case, the maxillary central incisor be through distolabiotorsiversion which is needed a good imagination of 3D tooth anatomically. In this case, a lack of understanding about imagination anatomy the tooth could be a reason iatrogenic perforation. After removing temporary cement, there was a cavity with dark spot which is tunnel-like. To detect the perforation, K-file was used to project the tunnel through mucosa gingival labial deliberately.

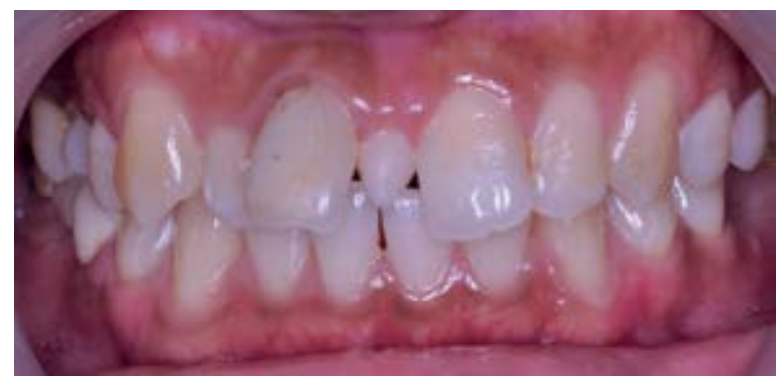

Figure 1.

Clinical appearance of the anterior teeth before the treatment. Maxillary right central incisor looks distolabiotorsiversion

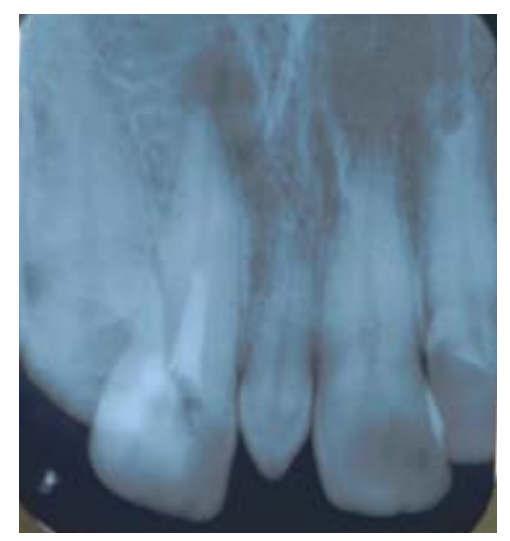

Figure 2.

New radiograph diagnosis was taken. There is a radiolucency at periapical of maxillary right central incisor. The previous operator did not read the radiograph carefully.

This method to evaluate clinical appearance perforation projection non surgically by spotting K-file at mucosa gingival labial. After scouting the the tunnel, periapical radiograph was taken to evaluate the perforation based on radiograph. Perforation is defined as a connection between the root canal treatment and the external surface of the toot caused by mechani- 
cal or pathological; which iatrogenic is the most commonly occurred. Perforations could occur in all tooth groups, but maxillary teeth take for $73 \%$ of the cases reported. Those perforations occurred resulting a connection from root canal system to labial aspect of the roots were due to a lack in access extension. Anatomically, maxillary central incisors have lingual shoulder which could prevents direct access to the root canal. The lingual shoulder must be removed to get access root canal system. A deficiencies access extension especially lingual shoulder resulting files deflected labially, or perforation. In addition, another risks at maxillary anterior teeth are the tooth pose (example rotation, malposition, etc.) and estimation of the palatal inclination in the upper jaw.

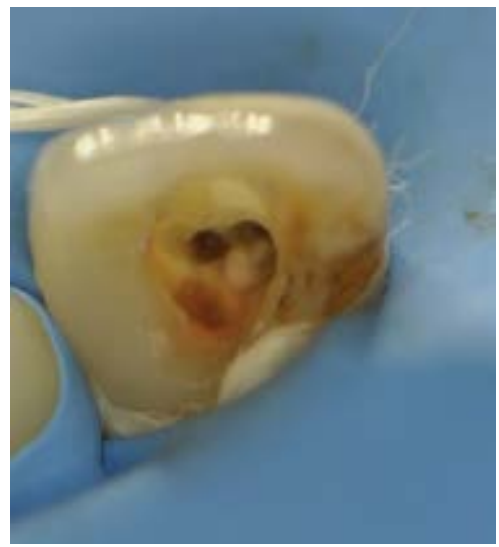

Figure 3.

Clinical appearance from incisal side. There were two spot of iatrogenic perforation (arrow)

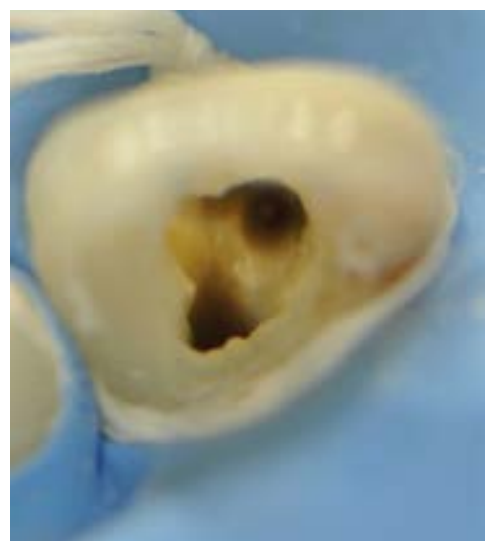

Figure 4.

Clinical appearance the tooth after locating the orifices.

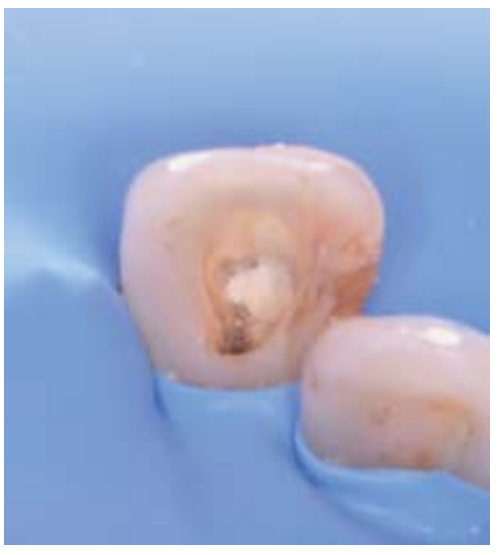

Figure 5.

Clinical appearance the perforation was sealed by MTA

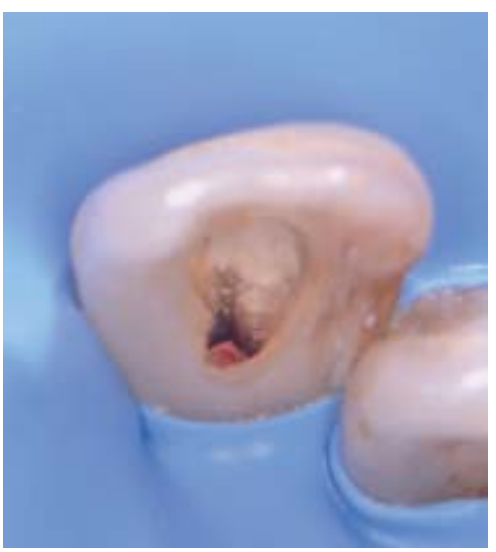

Figure 6

Clinical appearance the tooth has been done root canal treatment

Ever since iatrogenic perforation repair and other endodontic surgeries were done in unison with conventional root canal treatment, repair material selection plays important role to achieve good prognosis of those treatments. These materials should represent a proper seal of the root canal from both periradicular tissues and repair root defects. Anatomically, periradicular tissues contain many body fluids such as blood and other body fluids which produce wet or moist around periradicular tissues. The criteria of material needed is dimensional stability, solubility in tissue fluid, non-resorbability, radiopaque, bacteriostatic, ability to produce osteogenesis - cementogenesis, and the important thing is biocompatibility with periodontal tissues. Nevertheless, there are no materials offer of those properties. Numerous 
sealing materials have been tested over the years in search ideal material such as amalgam, zinc oxide eugenol, calcium hydroxide, glass ionomer cement, composite, MTA, and etc. After several studies, comparison between materials, MTA is commonly used for perforation repair.

MTA or mineral trioxide aggregate introduced by Torabinejad 20 years ago, consists of fine hydrophilic particles of tricalcium silicate, tricalcium aluminate, tricalcium oxide, silicate oxide, calcium sulphate dehydrate, tetracalcium aluminoferrite, and small amounts od mineral oxides (bismuthoxide). MTA is devived from Portland Cement with a slight difference in composition (Wen his wang). The major component (tricalcium silicate, tricalcium aluminate, etc) are responsible for the setting and biologic properties, and bismuth is only for radiopaque property. MTA can stimulates cementoblasts to produce matrix for cementum formation and biocompatible with periradicular tissue. After locating orifice and root canal, MTA was prepared to seal the perforation and isolating the root canal. MTA was mixed with the ratio $\mathrm{p}: 1=3: 1$, then it was applied using hand plugger. MTA was condensed using small head hand plugger intercrementally.

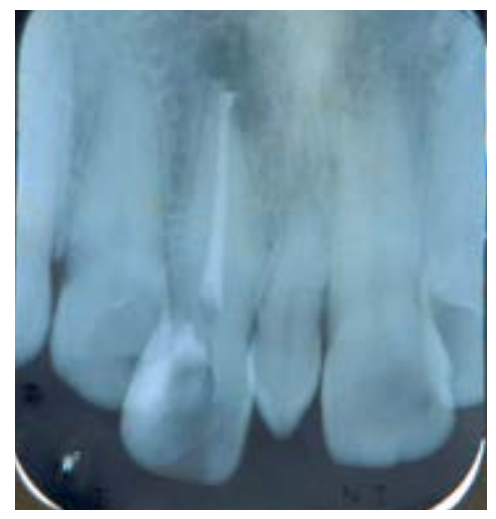

Figure 7.

Radiograph confirmation after root canal treatment and perforation sealing were done

Root canal treatment was done based on endodontic triads. Cleaning and shaping was achieved by biomechanical preparation. K-file was the major instrument while sodium hypochlorite $5 \%$ used for main irrigation. Sodium hypochlorite has been used widely as main irrigation because of its ability such as dissolve organic tissue, antibacterial and EDTA 15\% to remove smear layer which is produced during instrumentation. Irrigation procedure was done repeatedly after instrumentation. To improve cleaning root canal, combination sodium hypochlorite and EDTA were used based on previous studies. Microbial control was done with irrigating chlorhexidine $2 \%$ as a final irrigation. Chlorhexidine $2 \%$ was chosen because it is a wide-spectrum antimicrobial agent, active against gram-positive, gram-negative bacteria, and yeast. Moreover, chlorhexidine $2 \%$ can inhibits autodegradation extracellular matrix; matrix metalloproteinase (MMP) for improving resin-dentin bond stability. Distilled water was use between sodium hypochlorite and $\mathrm{CHX}$ to prevent parachloroaniline (PCA). Obturation was done using gutta percha and resin based sealer. Resin based sealer was chosen to achieve resin monoblock until the final restoration.

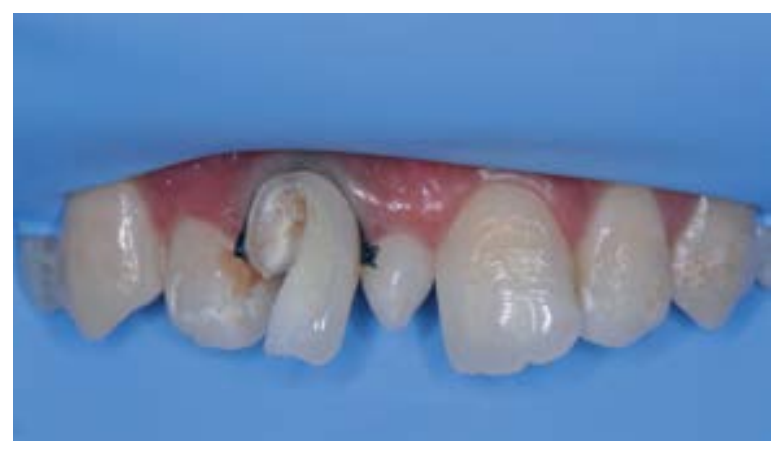

Figure 8.

The old restoration has removed while preparing for the restoration

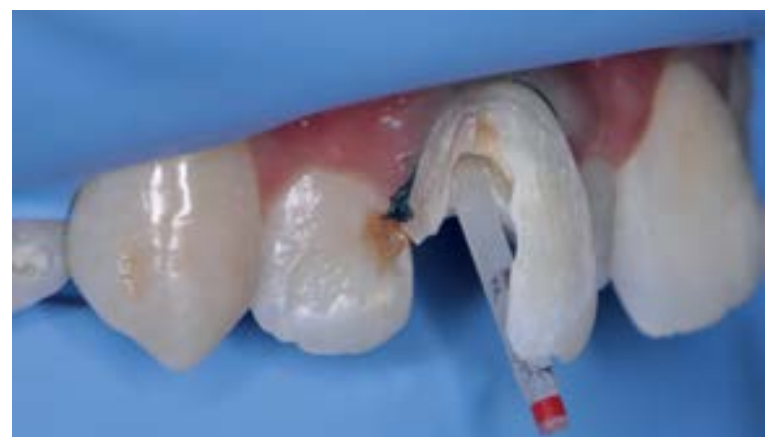

Figure 9.

Fiber post was inserted and being marked until two thirds of remaining crown. 


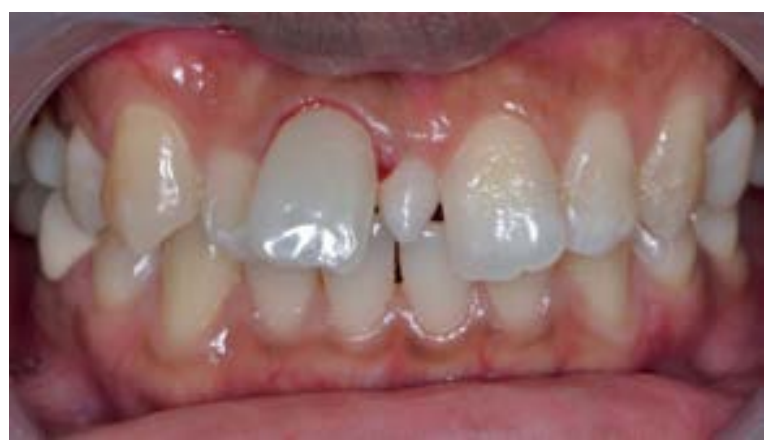

Figure 10.

The tooth was restored with composite resin directly. The restoration looks closer to the adjacent teeth

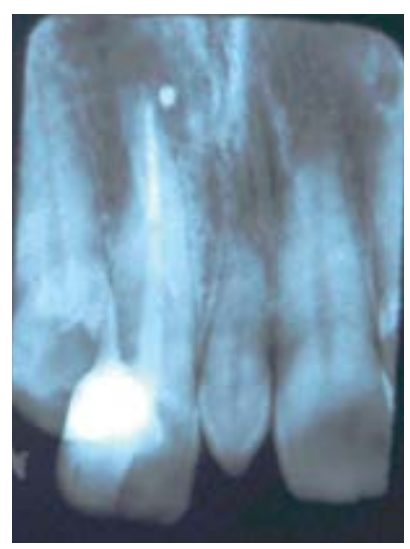

Figure 11.

Radiograph confirmation that tooth has been recovered.

After finishing root canal treatment, the old restoration and removing enamel unsupported dentin were done to consider the ideal restoration. Based on the rest of the hard tissue, the ideal restoration should be a crown with reinforcing using fiber post. The purpose of the restoration's plan was to seal coronal of the tooth while reinforcing the tooth and recovering the aesthetical aspect. To achieve the monoblock concept, resin based self adhesive resin cement and silanized fiber post were used. Not only for achieving monoblock concept, but also reinforcing the tooth. Fiber post was chosen because of the flexural properties closer to the dentin and aesthetical demand. How ever the issues of endodontically treated tooth is the tooth become brittle. Caries or trauma those causing loss structure of teeth leading to tooth more susceptible to fracture. But, some studies showed the differences is not significantly be- tween endodontically treated and vital tooth. The length of post was designed minimal intervention, $8 \mathrm{~mm}$ from the orifice and the diameter has been confirmed with comparing the precision drill's diameter to mesio-distal of the tooth at radiograph. The minimal extension consideration was to preserve tooth's structure as much as possible. The ideal restoration for this case is crown because of the remaining structure. Due to economical reason, direct restoration using composite resin was offered to recover the function of the tooth. The function of the anterior teeth is aesthetic. In this case, new nano-hybrid filler type composite resin with spherical filler was chosen to achieve a natural color compared to adjacent teeth. The size and form of filler give the restoration look smooth and shiny.

\section{CONCLUSION}

In summary, iatrogenic perforation can occur during the root canal treatment. Some materials have been found to repair perforation but none of them can be ideal. MTA has been found 20 years ago and becoming a first choice to repair the perforation. Since the root canal treatment could affect the loss of structure and moisture, the use of post for retention with minimal extension could be a choice for the treatment. Direct restoration could be used to achieve a good coronal seal and recovering the function with reachable price for many patients.

\section{ACKNOWLEDGEMENTS}

This case report has no any conflict interest with dental manufactures.

\section{BIBLIOGRAPHY}

Landolo A, Landolo G, Malvano M, Pantaleo G, Simeone M. Modern technologies in Endodontics. Giornale Italiano di Endodonzia. 2016;30:2-9

Kaushik A, Talwar S, Yadav, S, Chaudhary S, Nawal RR. Management of iatrogenic perforation with pulp canal obliteration. Saudi Endodontic Journal. 2014;4(3):141-144 
Mente J, Leo M, Panagidis D, Saure D, Pfefferle T. Treatment Outcome of Mineral Trioxide Aggregate: Repair of Root Perforations - Long-term Results. JOE. 2014;2(3):1-7

Cheung W. A review of the management of endodontically treated teeth Post, core, and the final restoration. JADA. 2005;136:611-619

Hargreaves KM, Berman LH. Cohen's Pathways of The Pulp. Missouri; 2016

Faria ACL, Rodrigues RCS, Antunes RPdA, de Mattos MdGC, Ribeiro RF. Review Endodontically treated teeth: Characteristics and considerations to restore them. Journal of Prosthodontic Research. 2015;55:69-74

Eliyas S, Jalili J, Martin N. Restoration of the root canal treated tooth. British Dental Journal. 2015;218(2): 53-62

McCabe PS. Avoiding perforations in endodontics. Journal of the Irish Dental Association. 2006;52(3):139-148
Wang WH, Wang CY, Shyu YC, Liu CM, Lin FH, Lin CP. Compositional characteristic and hydration behavior of mineral trioxide aggregates. J Dent Sci. 2010;5(2):53-59

Kakani AK, Veeramachaneni C, Majeti C, Tummala M, Khiyani L. A review on Perforation Repair Materials. Journal of Clinical and Diagnostic Research. 2015;9(9):9-13

Heymann HO, Swift EJ, Ritter AV. Sturdevant's Art and Science of Operative Dentistry, 6th Edition, Mosby. 2011

Kumaravadivel MS, Pradeep S. Recent Advancements of Endodontic Sealers - A Review. International Journal of Pharmacy \& Technology. 2016;8(2)4060-4075

Chan KHS, Mai Y, Kim H, Tong KCT, Ng D, Hsiao JCM. Review: Resin Composite Filling. Materials. 2010;3:1228-1243 